\title{
Edda Holl (2011): SPRACH-FLUSS - Theaterübungen für Sprachunterricht und interkulturelles Lernen. Ismaning: Hueber Verlag. ISBN 978-3-19-141751-2
}

\author{
Rachel Darby
}

The word „SPRACH-FLUSS“ (flow of language), depicts images of flowing rivers and streams; babbling, gurgling, murmuring along to their destination. They encounter obstacles, turn corners and meander but undeniably reach their goal.

SPRACH-FLUSS was a project held in the Sub-Saharan region of Africa in the years 2008 and 2009. 120 pupils and their teachers from 16 countries in Africa took part in these work-shops organised by the Goethe Institute in Johannesburg in conjunction with the Institute for Theatre and Media at the University of Hildesheim in Germany. Of these 120, 20 were invited to put what they learned to use, in a 'meet-and-greet' workshop in the Robert-Bosch secondary school in Hildesheim. The high point of this workshop was a stage performance at the Berlin Academy of Art, called "Sprachen ohne Grenzen“ (Languages without Borders).

The aim of the workshops, both in Africa and Germany, was for the pupils and teachers to experience through descriptive games, communication training, body work and personality development, a livelier, more enjoyable and more effective method of learning and teaching German. The participants experienced the German language as an international means of communication, during the various interactive exercises they turned corners and meandered but worked hard to pursue their communicative goals.

The follow-up booklet is a refreshing look at language learning and teaching through drama. It outlines its aims clearly, and describes many easy-to-follow drama activities.

This book is different to other drama activity texts in that the emphasis is on the acquisition of „Sprachbewusstheit“ (language awareness). A very enthusiastic and complimentary foreword by Robert Fallenstein of the Goethe Institut in Johannesburg (Director of the language department for the Sub-Saharan region in Africa), remarks on how all languages, dialects and sociolects, as well as the target language are welcome in the foreign language classroom. This viewpoint is quite different from that of many language teachers, who use either exclusively the target language or a combination of target language and the students' "first" language.

The author points out that there are 1,500 languages spoken in Africa which shows that multilingualism is a basic aspect of African students' cultural identity. 
Even before going to school, children here are used to communicating in three or four languages. The central question to this project was how to use this natural learning of languages in the classroom. Holl realises the key is to concentrate on the building of an awareness of the individual's and group's multilingual potential rather than just focusing on developing skills in the target language; to allow the different languages and dialects, and thereby the different cultures, be an intrinsic part of the learning process. The SPRACH-FLUSS workshops provided a perfect setting for this.

Zum anderen sollten interaktive Formen erprobt und erkundet werden, durch die sämtliche Sprachkenntnisse der Jugendlichen zutage gefördert und erlebbar gemacht werden konnten,um so deren Sprachbewusstheit auszubilden. Daher wurden bei den Workshops etliche Möglichkeiten ausprobiert, die verschiedenen Muttersprachen, Dialekte und Soziolekte im Raum hörbar zu machen und diese dann phonetisch mitsprechen zu lassen. (10)

It is claimed that this development of language awareness helps learners to appreciate the learning of new languages, and feel confident about using them in real-life situations, and ultimately helps them to adopt responsibility for their own learning.

Holl explains where the roots of her theory come from. She refers to the research of Joan Rubin (University of Hawaii), who listed the traits of 'good language learners'. In short, they are not afraid to make mistakes and learn from the ones they do, they act 'as if' they know what is being talked about even if they do not, they make educated guesses at words or structures, and use every opportunity to speak the language and build their language awareness.

Holl emphasises that the 'good language learners' take the learning process into their own hands and bring their own knowledge and personality to it. She adds that conscious language learning (learning vocabulary and grammar rules) must go hand-in-hand with unconscious (spontaneous, intuitive) language learning, and that it is through social and communicative interaction and skill that an independent language learning process can advance. The social art-form of theatre is an intensive, all-encompassing form of communication, which makes it an ideal field of inspiration for modern language teachers.

The rest of the book's introduction, before the drama exercises are introduced, reiterates the belief that using drama is a creative, fulfilling and successful method to learn to communicate. Drama encourages learners to 'adopt' a role and act as if they 'can speak the language'.

Vielen KT [(Kursteilnehmer)] hilft es, im Schutz einer Figur zu agieren.

Sie sind unbefangener, wenn sie in eine Rolle schlüpfen und einfach so tun können, „als ob“ sie die fremde Sprache sprächen. (13)

Holl states that feedback by the 'audience' (the other pupils) is one of the most important aspects of the SPRACH-FLUSS work. The participants realise how much they can learn from each other as well as themselves. This observation and reflection brings a deeper appreciation and understanding of the language. 
Holl presents a number of practical and exercises from the workshops (some of which are presented in the form of short film clips on the DVD accompanying this booklet). These are divided into four sections: I. Kreise/Rhythmen, II. Partner/Impulse, III. Körper/Sprache, IV. Kommunikation/Raum. They are introduced by a list of „Sprachkompetenzen“ (language skills). The exercises themselves are entertaining and insightful, well-explained and with clear aims. After each exercise, she outlines precisely what the learner can hope to achieve and also gives „Varianten“ (alternatives) for most exercises.

In some exercises, the learner is told to 'freeze' after saying a certain phrase. This adds weight to the phrase, allows the learner a moment to absorb it, and fastens it in the learners mind. The following three, randomly selected examples give a taste of the type of exercises presented in Holl's booklet.

"Sambakreis" is an exercise which aims at putting rhythm to words. First, the workshop leader presents a sequence of rhythmic movements which are repeated and until all students feel confident about the sequence. Then, text (a small poem or dialogue or passage from a textbook) is 'incorporated' into the exercise. The students speak the text in keeping with the practiced rhythm, thus experiencing an interesting interplay of language, movement and rhythm.

In „Impulskreis“, Holl makes a good point about the fact that learners hesitate slightly before speaking a foreign language. The exercises in "Impulskreis“ emphasise the need to react immediately, thereby helping the learner get over this hesitancy.

In „Spiegel mit Sprache“, one learner mimics the other's gestures and mouth movements as the first speaks in their own dialect or language, which is unknown to the second learner. This emphasises awareness of speaking a foreign or unknown language.

Sprachfluss describes drama activities used in a particular project with particular pupils for a particular venture. Holl states that the exercises in this book are ideal for anyone who wants to go studying or working in Germany; through the SPRACH-FLUSS approach they will learn the language similar to immigrants learning German in Germany as a second language. Looking through this booklet with secondary school classrooms in Ireland in mind, I see vast potential to use these exercises in various forms in the classroom. However, adapting them is absolutely necessary, and Holl could have given more time to dealing with the restrictions of class-size, space and time when dealing with a typical school-day in any country, especially as the pupils in the project are in second-level education. And I would have liked to have seen more of a link-up between the exercises, like a lesson plan with a main goal. Some of the exercises do follow on from each other, but an end result seemed to be lacking.

Over the last twenty years a lot of research (especially in Europe, the US and Asia) has focused on drama pedagogy in language teaching. It seems that the 'communicative' language classrooms we have been used to, are turning more and more into 'performative' classrooms. While it is very interesting to hear more about drama-based language teaching in Africa, the author regretfully has made no attempt to situate her approach within the lively international subject 
debate revolving around drama and theatre in the modern language classroom.

Nonetheless this book has brought new and exciting drama activities to my attention. The concept of emphasising "Sprachbewusstheit" is one I wholly agree with, and the allowance of other languages and cultures into the foreign language classroom is something that can enrich the learning process. This project seems to have broken new ground, and the experiences of these teachers, pupils and practitioners can enlighten and inspire those of us already passionate about this methodology. 